\title{
Elevated plasma cortisol reduces permeability of mammary tight junctions in the lactating bovine mammary epithelium
}

\author{
K Stelwagen, D C van Espen ${ }^{1}$, G A Verkerk ${ }^{2}$, H A McFadden and \\ V C Farr \\ Dairy Sciences, AgResearch, ${ }^{2}$ Dairying Research Corporation, Ruakura Research Centre, Private Bag 3123, Hamilton, New Zealand and \\ ${ }^{1}$ Wageningen Agricultural University, Wageningen, The Netherlands \\ (Requests for offprints should be addressed to K Stelwagen)
}

\begin{abstract}
Induction of tight junction permeability in the mammary epithelium decreases milk secretion, and in cows tight junctions become leaky after $17 \mathrm{~h}$ of milk accumulation. In vitro studies demonstrate the importance of glucocorticoids for the formation and maintenance of tight junctions. In this study we examined whether cortisol can prevent mammary tight junction permeability in the lactating gland in vivo, and inhibit the associated milk loss, using our milk-accumulation model to challenge tight junction patency. Following a 4-day control period Jersey cows were subjected to a $24-\mathrm{h}$ period in which they were milked twice at 0700 and $1500 \mathrm{~h}(\mathrm{TM} ; n=6)$, once at $0700 \mathrm{~h}(\mathrm{OM} ; n=7)$, or once and treated with ACTH (40 IU per $2 \mathrm{~h}$, starting after $14 \mathrm{~h}$ of milk accumulation) to increase endogenous cortisol levels $(\mathrm{OM}+\mathrm{ACTH} ; n=7)$. Frequent blood samples for cortisol, lactose and glucose analyses were taken via indwelling jugular catheters.
\end{abstract}

ACTH treatment resulted in a sustained elevation of systemic cortisol concentrations. Plasma lactose, an indicator of tight junction leakiness, was not changed in TM cows, but began to increase rapidly at $17 \mathrm{~h}$ of milk accumulation in OM cows. Treatment with ACTH prevented the increase in plasma lactose, although levels were slightly, but not significantly, higher than in TM cows, indicating that elevated plasma cortisol reduced mammary tight junction leakiness. Milk yield was reduced by $12 \%$ in both once-milked groups, despite cortisol preventing tight junction leakiness. However, the milk loss in the latter group may not be related to leaky tight junctions, but be due to a reduction in milk precursor uptake by the mammary gland. Consistent with this notion was a $34 \%$ increase in plasma glucose levels in $\mathrm{OM}+\mathrm{ACTH}$ cows only.

Journal of Endocrinology (1998) 159, 173-178

\section{Introduction}

The tight junction or zonula occludens, a 'gasket-like' structure, is part of the junctional complex and surrounds endothelial or epithelial cells in close proximity to the cell's apical domain. When intact, it prevents the vectorial movement of small molecules and ions between the basolateral and apical sides of cells. This 'barrier' function of the tight junction permits the existence of pools of ions and/or small molecules differing in concentration on either side of the cell. In addition, tight junctions are instrumental in maintaining the polarised state of secretory cells, by preventing redistribution of plasma membrane components (e.g. ion channels and ion pumps) and maintaining a difference in lipid and protein composition between the basal and apical side of the plasma membrane. The latter function of the tight junction is often referred to as its 'fence' function (Schneeberger \& Lynch 1992, Mandel et al. 1993).

In the mammary gland, epithelial tight junctions, when 'tight', form a barrier between the blood, or more precisely the interstitial fluid (basolateral side), and milk in the alveolar lumen (apical side), thus preventing serum components from entering into milk and vice versa (Stelwagen et al. 1995). In the periparturient period (Linzell \& Peaker 1974) and again as the mammary gland involutes, towards the end of lactation (Fleet \& Peaker 1978), tight junctions are 'leaky'. However, it was shown recently that the permeability of tight junctions can increase during established lactation if milk is allowed to accumulate. In cows, tight junctions switch to a leaky state after approximately $17 \mathrm{~h}$ of milk accumulation (Stelwagen et al. 1997a), and in goats after $21 \mathrm{~h}$ (Stelwagen et al. 1994b). Furthermore, this increase in permeability is associated with a reduction in milk secretion (Neville \& Peaker 1981, Stelwagen et al. 1994b, 1997a), and an increase in protease activity in milk (Stelwagen et al. 1994c).

Although there is evidence from in vitro experiments on colonic and intestinal epithelia that insulin-like growth factors-I and -II and insulin are involved in modulating the permeability of tight junctions (McRoberts et al. 1990, McRoberts \& Riley 1992), little is known about 
endocrine factors that regulate mammary epithelial tight junctions. Growth hormone, although important for maintaining milk secretion, does not appear to be important for the maintenance of mammary tight junctions in rats (Flint \& Gardner 1994) and cows (Stelwagen et al. 1994a). Lactogenesis, the period during which mammary tight junctions are formed, requires the presence of prolactin, insulin and glucocorticoids (Forsyth 1982), but neither prolactin nor insulin was found to affect tight junctions in a murine mammary epithelial cell line (Zettl et al. 1992). In contrast, addition of dexamethasone, a synthetic glucocorticoid, to the medium of cultured mammary cells significantly reduces tight junction permeability (Zettl et al. 1992). Those authors concluded that glucocorticoids play an important role in the maintenance and formation of mammary tight junctions. The objectives of the present study were to examine whether cortisol reduces the permeability of mammary tight junctions in vivo, in the lactating mammary epithelium, and prevents the associated reduction in milk secretion. Our previously described milk-accumulation model (Stelwagen et al. 1997a) was used to challenge mammary tight junctions.

\section{Materials and Methods}

\section{Animal care and use}

Twenty multiparous Jersey cows during the early stage of lactation (68 \pm 10 days postpartum) were used. During the study the cows were kept in large, partly covered, individual pens. The diet of freshly cut clover-ryegrass pasture was fed at 0800 and $1700 \mathrm{~h}$. Fresh water was available throughout the experiment. Cows were machine milked at 0700 and $1600 \mathrm{~h}$, or, in the case of once-daily milking, at $0700 \mathrm{~h}$. Animal experimentation was conducted in accordance with the guidelines of the Ruakura Animal Ethics Committee.

\section{Experimental protocol}

Following a control period of 4 days, during which all cows were treated in the same manner, they were randomly assigned to one of three groups at the start of the subsequent 24-h experimental period. Groups were a control group milked twice (TM, $n=6$ ), a group milked only once (OM, $n=7)$, and a group that was milked once and treated with adrenocorticotrophin (ACTH) (OM+ ACTH, $n=7$ ). A dose of $0.05 \mathrm{mg}$ (40 IU) of ACTH (ACTH $_{(1-24)}$, Synachten, CIBA-Geigy, Switzerland) was administered five times in a total volume of $2 \mathrm{ml}$ saline per dose into a jugular vein. Treatments were administered every $2 \mathrm{~h}$, starting at $14 \mathrm{~h}$ of milk accumulation. The dose level was chosen based on previous data (Verkerk et al. 1994), to ensure that an elevation in plasma cortisol concentration was sustained with a low dose of ACTH and as few injections as possible. The time for the initial dose (i.e. at $14 \mathrm{~h}$ ) was chosen so that cortisol levels were elevated before mammary tight junctions became leaky, shown recently to occur consistently at $17 \mathrm{~h}$ of milk accumulation (Stelwagen et al. 1997a).

Three days before the experimental period, indwelling jugular catheters (Cavafix Certo, B Braun Melsungen, Melsungen, Germany) were inserted in each cow to facilitate repeated blood sampling and administration of ACTH. Following each blood sampling, catheters were flushed with heparinised $(50 \mathrm{IU} / \mathrm{ml}$; Leo Pharmaceutical Products, Ballerup, Denmark) saline. Blood samples were collected every $2 \mathrm{~h}$ during the first $10 \mathrm{~h}$ and hourly for the remainder of the 24-h experimental period. To more accurately describe the systemic cortisol profiles, samples were also taken from $\mathrm{OM}+\mathrm{ACTH}$ cows $30 \mathrm{~min}$ following each ACTH treatment.

Milk yields were recorded at each milking throughout the control and experimental periods. Composite whole milk samples $(25 \mathrm{ml})$ were also collected from each cow at every milking.

A mammary biopsy was taken after $23 \mathrm{~h}$ of milk accumulation from two randomly chosen cows from each group. No data of tissue analyses are reported, but all subsequent milk yield and composition data from these six cows are not included in the statistical analyses of the present study.

\section{Chemical analyses}

Blood samples were collected in heparinised vacutainers and stored on ice until centrifugation at $1500 \mathrm{~g}$ for $15 \mathrm{~min}$. Plasma was aspirated and stored at $-20{ }^{\circ} \mathrm{C}$ until analysed for cortisol, lactose or glucose. Total cortisol was measured by a fluorescence polarisation assay, as previously reported (Verkerk et al. 1994). Inter- and intra-assay coefficients of variation were less than $10 \%$ and assay sensitivity was $0.5 \mathrm{ng} / \mathrm{ml}$. Recovery of unlabelled antigen was $93 \%$. Lactose in plasma was analysed using an enzymatic method as described previously (Stelwagen et al. 1994a). Glucose in plasma was analysed using a Hitachi 717 random access autoanalyser (Boehringer Mannheim NZ Ltd, Auckland, New Zealand).

The somatic cell count and the concentration of fat, protein and lactose were measured in fresh whole milk samples using a cell counter (somatic cell count) and standard infra red analyses (milk composition) as outlined previously (Stelwagen et al. 1994a).

\section{Statistical analyses}

All statistical analyses were carried out using SAS (SAS System for Windows, Release 6.11 1996, SAS Institute Inc., Cary, NC, USA). Differences between treatments were evaluated by ANOVA, including a covariate as appropriate $(P<0 \cdot 05)$. The covariate used for the ANOVA of milk yield, somatic cell count, fat, protein or lactose 
percentage was the average for each respective variable during the 2 days preceding the experimental period. Milk yield was also included as a covariate for the ANOVA of plasma lactose. Because it was important to compare treatments at different time points and the likelihood that data were correlated, plasma lactose data were first subjected to multivariate analyses of variance (MANOVA). The MANOVA indicated a significant treatment effect, hence univariate ANOVAs were carried out subsequently for each time point.

The treatment profiles for cortisol appeared to increase over time. To determine whether these increases were significant, regression lines were fitted through the data of each animal, starting from $14.5 \mathrm{~h}$. Regression coefficients were then tested per treatment to determine whether they were significantly greater than zero, using paired $t$-test analysis. To determine whether the slopes differed among treatment groups, regression coefficients were analysed by ANOVA.

The calculations to determine when the level of lactose in the plasma began to increase (i.e. when tight junction permeability changed) have been described previously (Stelwagen et al. 1997a). Briefly, the average concentration of the first four 2-hourly measurements is compared with the concentration at each subsequent time point. Then the time point at which the difference becomes significant $(P<0 \cdot 05)$ is taken to indicate the onset of tight junction leakiness.

Means presented are least square means. In the case of multiple means (ANOVA) standard errors (S.E.M.) are reported as the average S.E.M. for the three treatment groups.

\section{Results}

\section{Concentration of cortisol in plasma}

The first dose of ACTH caused a rapid $(<0.5 \mathrm{~h})$ increase in the concentration of plasma cortisol in cows in the $\mathrm{OM}+\mathrm{ACTH}$ group (Fig. 1A). Subsequent treatments sustained these significantly elevated cortisol levels throughout the desired time frame, whereas no differences were observed between the TM and OM groups. Mean plasma cortisol concentrations between 14.5 and $23 \mathrm{~h}$ of milk accumulation were: TM vs $\mathrm{OM}$ vs $\mathrm{OM}+\mathrm{ACTH}$, $4 \cdot 6^{\mathrm{a}}$ vs $7 \cdot 3^{\mathrm{a}}$ vs $54 \cdot 7^{\mathrm{b}} \pm 2 \cdot 4 \mathrm{ng} / \mathrm{ml}\left({ }^{\mathrm{ab}} P<0 \cdot 0001\right)$. Even at its lowest point, at $18 \mathrm{~h}$, the concentration was still significantly higher than in the TM and OM groups (TM vs $\mathrm{OM}$ vs $\mathrm{OM}+\mathrm{ACTH}, 1 \cdot 6^{\mathrm{a}}$ vs $2 \cdot 6^{\mathrm{a}}$ vs $32 \cdot 7^{\mathrm{b}} \pm 4 \cdot 3 \mathrm{ng} / \mathrm{ml}$, $\left.{ }^{\mathrm{ab}} P<0 \cdot 0001\right)$.

There appeared to be a slight, albeit significant $(P<0 \cdot 05)$, increase in the cortisol profiles as the time of milk accumulation progressed. The increase was greater for $\mathrm{OM}+\mathrm{ACTH}$ cows than for cows in the other two groups, for which the regression coefficients did not differ (TM vs OM vs OM+ACTH, $0 \cdot 63^{\mathrm{a}}$ vs $1 \cdot 20^{\mathrm{a}}$ vs $\left.3 \cdot 18^{\mathrm{b}} \pm 0 \cdot 28,{ }^{\mathrm{ab}} P<0 \cdot 0001\right)$.
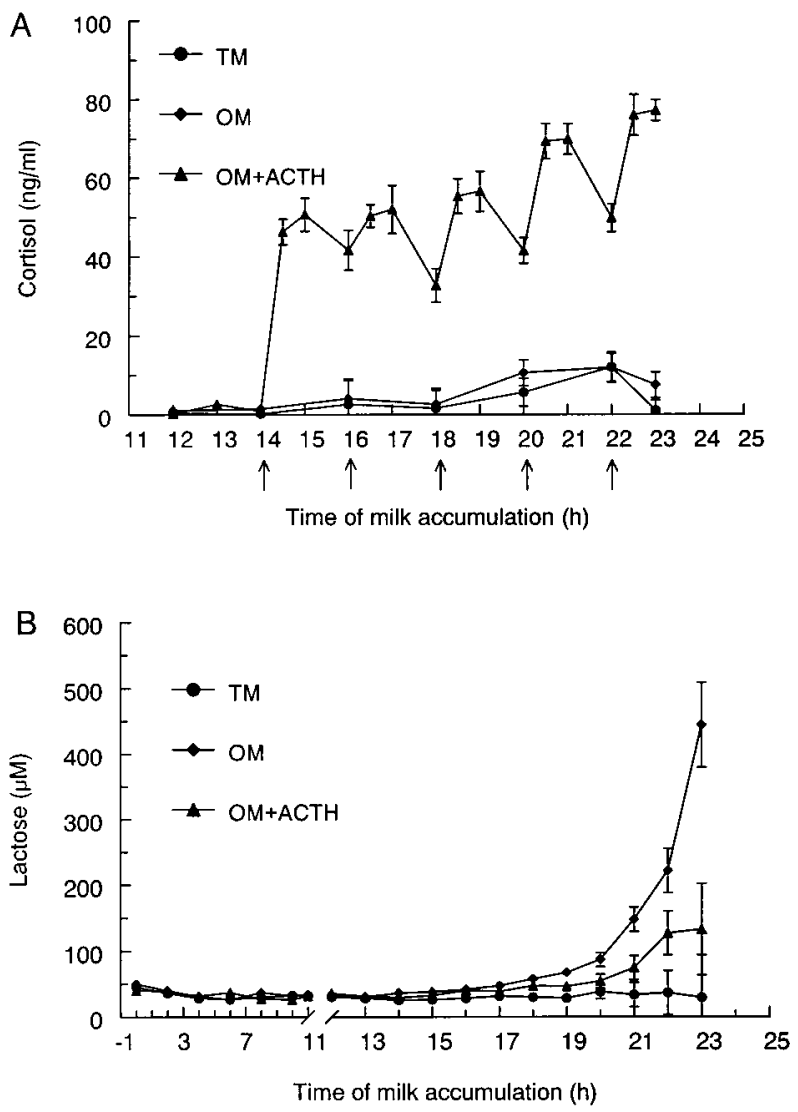

Figure 1 Concentrations of cortisol (A) and lactose (B) in plasma of cows milked twice (TM) or once (OM) during the 24-h experimental period. One OM group received $40 \mathrm{IU}$ of ACTH every $2 \mathrm{~h}$ starting at $14 \mathrm{~h}$ of milk accumulation $(\mathrm{OM}+\mathrm{ACTH})$. Arrows indicate when ACTH was administered. Values are the mean \pm S.E.M. of six (TM) or seven (OM, OM+ACTH) cows. Where error bars are not visible the S.E.M. was smaller than the plotting symbol.

\section{Concentration of lactose in plasma}

The concentrations of lactose in plasma, an indicator of mammary tight junction permeability, are shown in Fig. 1B. In cows in the TM group the concentration did not increase, and, in fact, remained at basal levels throughout the experimental period. The profile for OM cows, on the other hand, showed a typical rapid increase, becoming significant after $17 \mathrm{~h}$ of milk accumulation. The concentration of plasma lactose in cows with elevated plasma cortisol levels (ACTH treatment) was significantly lower compared with that in OM cows. Although lactose concentrations tended $(P>0 \cdot 10)$ to be higher from $19 \mathrm{~h}$ onwards in ACTH-treated cows than in TM cows, at no time point were they statistically different. Mean concentrations of plasma lactose at the final measurement at $23 \mathrm{~h}$ of milk accumulation were: TM vs $\mathrm{OM}$ vs $\mathrm{OM}+\mathrm{ACTH}$, $29 \cdot 4^{\mathrm{a}}$ vs $444 \cdot 2^{\mathrm{b}}$ vs $132 \cdot 9^{\mathrm{a}} \pm 66 \cdot 3 \mu \mathrm{M}\left({ }^{\mathrm{ab}} P<0 \cdot 01\right)$. 


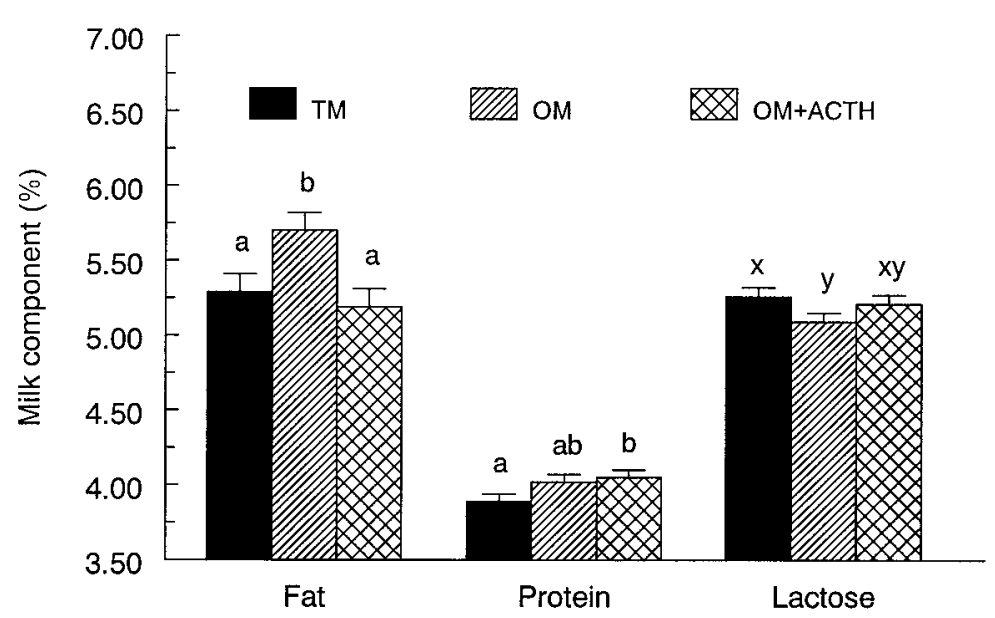

Figure 2 Changes in the concentrations of fat, protein and lactose in the milk of cows milked twice (TM) or once (OM) during the 24-h experimental period. One OM group received $40 \mathrm{IU}$ of ACTH every $2 \mathrm{~h}$ starting at $14 \mathrm{~h}$ of milk accumulation $(\mathrm{OM}+\mathrm{ACTH})$. ${ }^{\mathrm{a}, \mathrm{b}}$ Means differ at $P<0 \cdot 05$. ${ }^{\mathrm{x}, \mathrm{y}}$ Means differ at $P<0 \cdot 07$. Values are the mean \pm S.E.M. of six $(T M)$ or seven $(\mathrm{OM}, \mathrm{OM}+\mathrm{ACTH})$ cows.

\section{Milk composition and yield}

Means for milk fat, protein and lactose content at the end of the experimental period are shown in Fig. 2. Fat content was significantly elevated by once-daily milking, but this increase appeared to be prevented by ACTH treatment (i.e. in OM+ACTH cows). Protein content of the milk, on the other hand, was greater for both once-milked groups, and was not affected by ACTH treatment. Compared with the TM group, milk lactose, the major osmoregulatory component in milk, tended to be lower in the OM group, but not in the OM+ACTH cows. The somatic cell count, an indicator of mammary health status, comprises predominantly white blood cells. Counts were low $(<50000 / \mathrm{ml})$ throughout the control and experimental period, and did not differ among the treatment groups (log-transformed somatic cell counts: TM vs OM vs OM+ACTH, 4.63 vs $4 \cdot 60$ vs $4 \cdot 62 \pm 0 \cdot 1$ cells $/ \mathrm{ml})$. Compared with that of TM cows, milk yield was approximately $12 \%$ lower in the once-milked cows, regardless of ACTH treatment ( $\mathrm{TM}$ vs $\mathrm{OM}$ vs $\mathrm{OM}+\mathrm{ACTH}, 16 \cdot 3^{\mathrm{a}}$ vs $14 \cdot 4^{\mathrm{b}}$ vs $14 \cdot 4^{\mathrm{b}} \pm 0 \cdot 4 \mathrm{~kg} /$ day, $\left.{ }^{\mathrm{ab}} P<0 \cdot 05\right)$.

\section{Concentration of glucose in plasma}

The concentrations of glucose in the plasma, measured at $23 \mathrm{~h}$ of milk accumulation, were: TM vs $\mathrm{OM}$ vs $\mathrm{OM}+$ ACTH, $4 \cdot 20^{\mathrm{a}}$ vs $4 \cdot 21^{\mathrm{a}}$ vs $5 \cdot 64^{\mathrm{b}} \pm 0 \cdot 1 \mathrm{mM}\left({ }^{\mathrm{ab}} P<0 \cdot 001\right)$. Concentrations were significantly greater in ACTHtreated cows, but did not differ between TM and OM groups. Because glucose is the major precursor for lactose, we estimated how much milk the increase in plasma glucose represents if it were to be used as a milk precursor, using the following assumptions: (1) the concentration of glucose in the plasma rises to a constant level within $3 \mathrm{~h}$ of the first ACTH administration, based on cortisol infusion data (Stewart \& Thompson 1984); (2) no other precursors are limiting, and plasma-derived glucose is the sole source of mammary glucose; (3) $2 \mathrm{~mol}$ glucose are required for 1 mol lactose; and (4) $85 \%$ of the glucose taken up by the mammary gland is used for lactose synthesis (Annison \& Linzell 1964). The glucose excretion rate is a function of its clearance from the plasma and its concentration. Using the clearance rate of $17 \cdot 2 \mathrm{ml} / \mathrm{min}$ per $\mathrm{kg}^{0 \cdot 75}$ body weight, obtained by Hartmann \& Kronfeld (1973) for lactating cows of similar body weight and milk production as the cows in the present study, it follows that the decrease in mammary glucose uptake in ACTH-treated cows is $23.4 \mathrm{~g} / \mathrm{h}$ or $139.3 \mathrm{~g}$ in $7 \mathrm{~h}$ with an $85 \%$ utilisation rate. At $2 \mathrm{~mol}$ glucose per $1 \mathrm{~mol}$ lactose this represents $70 \mathrm{~g}$ of lactose and $1.3 \mathrm{~kg}$ of milk (i.e. $52.4 \mathrm{~g}$ of lactose per $\mathrm{kg}$ of milk, Fig. 2), a figure that is quite close to the actual decrease in milk yield of $1.9 \mathrm{~kg}$.

\section{Discussion}

Earlier studies have demonstrated the importance of mammary tight junctions in maintaining milk secretion (Stelwagen et al. 1994b, 1995, 1997a). Moreover, glucocorticoids play an important role in the formation and maintenance of mammary tight junctions in vitro (Zettl et al. 1992). In the present study we used an in vivo model to examine whether elevated levels of plasma cortisol decrease permeability of tight junctions in the lactating gland, and in consequence prevent milk loss associated with increased tight junction leakiness. 
Cortisol levels were successfully elevated by ACTH during the desired time frame. However, in all groups the cortisol profiles increased towards the latter part of the treatment period. This may be due to stress from the frequent blood sampling regime and/or interference with rumination and sleep patterns, because stress elevates cortisol levels in cows (Verkerk et al. 1998). Furthermore, Lefcourt et al. (1993) reported that cows exhibit weak circadian rhythms, with cortisol levels reaching a maximum at $0530 \mathrm{~h}$. Indeed, levels also peaked in cows in the TM and OM groups at that time (i.e. $22 \mathrm{~h}$ ).

Lactose in plasma was the main indicator of mammary tight junction permeability in the present study. Lactose is only produced in the mammary gland, and because it is not secreted basolaterally (Stelwagen et al. 1998b) its presence in blood can only be explained by its movement from milk into blood via leaky tight junctions. We have extensively validated the use of plasma lactose as a reliable indicator of tight junction permeability (Stelwagen et al. 1994b, 1995, 1997a). The increase in plasma lactose at $17 \mathrm{~h}$ of milk accumulation in OM cows is in agreement with tight junctions becoming consistently leaky after this time (Stelwagen et al. 1997a, 1998a). Compared with that in OM cows, the concentration of lactose in plasma was significantly reduced in ACTH-treated cows. These data represent the first in vivo evidence that cortisol can reduce tight junction permeability in the lactating mammary gland, and support in vitro studies (Zettl et al. 1992). Although concentrations in ACTH-treated cows were not statistically different from those in TM cows, they tended to be higher after $19 \mathrm{~h}$ of milk accumulation. This suggests that although the onset of leakiness was delayed by $2 \mathrm{~h}$, cortisol did not completely prevent the effect of milk accumulation on the tight junctions. The reason(s) for this remain(s) elusive. A higher level of cortisol may be required, or levels need to be elevated earlier. It is possible that the initiation of the change in permeability of tight junctions, which are closely linked to the cytoskeleton of the cell (Schneeberger \& Lynch 1992), started before cortisol was elevated. Alternatively, as mentioned earlier, the frequent sampling protocol may have elicited a stress response towards the end of the 24-h period, and preliminary data suggest that stress may adversely affect mammary tight junctions (Stelwagen et al. 1997b, McFadden \& Stelwagen 1998). The small changes in milk composition between TM and OM cows are consistent with previous data (Stelwagen et al. 1994a, 1997a). The fact that the lactose level in milk of ACTH-treated cows was not different from that in TM cows supports the data on plasma lactose, because when tight junctions are open lactose 'leaks' from milk into plasma (Stelwagen et al. 1997a).

The $12 \%$ decrease in milk yield in OM cows is well within the range previously observed with once-daily milking (Stelwagen et al. 1994a, 1996, 1997a). The reduction in milk secretion is due to local, intramammary, mechanisms (Wilde et al. 1987, Stelwagen \& Knight
1997). Although the exact mechanisms underlying such control are not known, they are likely to involve a putative inhibitory protein which has been isolated from milk (Wilde et al. 1995), as well as modulation of mammary tight junction patency (Stelwagen et al. 1994b, 1995, 1997a). Therefore, given the fact that ACTH reduced tight junction permeability, we did not expect milk yield to be reduced to the extent as shown for the ACTHtreated cows. However, milk loss in these cows may be related to factors other than tight junctions. In ruminants exogenous glucocorticoids significantly lower glucose extraction by the mammary gland, resulting in higher systemic glucose levels (Hartmann \& Kronfeld 1973, Kronfeld \& Hartmann 1973, Stewart \& Thompson 1984). Therefore, the fact that plasma glucose levels were not different between TM and OM groups, but were 34\% higher in the ACTH-treated cows, suggests that mammary uptake of glucose was reduced in the latter group. With glucose being the major precursor for milk lactose, which is the predominant osmoregulatory component in milk, the lower milk yield in the ACTH-treated cows may thus be due to a decrease in precursor supply, rather than being related to tight junction patency. Indeed, our calculations (see Results) show that the increase in plasma glucose in the $\mathrm{OM}+\mathrm{ACTH}$ group represents a precursor pool that might explain the milk loss in these cows. It may be possible to overcome the confounding effects of glucocorticoids on milk secretion, by minimising the cortisol increase necessary to maintain tight junction patency. After all, cortisol levels in the present study were approximately three times higher then levels occurring naturally during lactogenesis, when mammary tight junctions are formed (Paterson \& Linzell 1971, Hudson et al. 1976).

Finally, the present study does not address the mechanism by which cortisol modulates tight junctions. However, disruption of phosphorylation/dephosphorylation events and transforming growth factor- $\alpha$ can override the effects of glucocorticoids on mammary tight junctions in vitro, by causing a redistribution of the tight junction-associated protein, ZO-1 (Singer et al. 1994, Buse et al. 1995a,b). The ZO-1 protein is a cytoplasmic plaque protein, linking the integral tight junction protein occludin to the actinbased cytoskeleton (Fanning et al. 1996). To ascertain that such a mechanism underlies the in vivo changes observed in the present experiment requires further study.

\section{Acknowledgements}

Financial support was provided by the Foundation for Research, Science and Technology of New Zealand.

\section{References}

Annison EF \& Linzell JL 1964 The oxidation and utilization of glucose and acetate by the mammary gland of the goat in relation to their over-all metabolism and to milk formation. Journal of Physiology 175 372-385. 
Buse P, Woo PL, Alexander DB, Cha HH, Reza A, Cirota ND \& Firestone GL 1995a Transforming growth factor-alpha abrogates glucocorticoid-stimulated tight junction formation and growth suppression in rat mammary epithelial tumor cells. Journal of Biological Chemistry 270 6505-6514.

Buse P, Woo PL, Alexander DB, Cha HH, Reza A \& Firestone GL $1995 b$ Glucocorticoid-induced functional polarity of growth factor responsiveness regulates tight junction dynamics in transformed mammary epithelial tumor cells. Journal of Biological Chemistry 270 28223-28227.

Fanning AS, Lapierre LA, Brecher AR, Van Itallie CM \& Anderson JM 1996 Protein interactions in the tight junction: the role of MAGUK proteins in regulating tight junction organization and function. Current Topics in Membranes 43 211-235.

Fleet IR \& Peaker M 1978 Mammary function and its control at the cessation of lactation in the goat. Journal of Physiology 279 491-507.

Flint DJ \& Gardner M 1994 Evidence that growth hormone stimulates milk synthesis by direct action on the mammary gland and that prolactin exerts effects on milk secretion by maintenance of mammary deoxyribonucleic acid content and tight junction status. Endocrinology 135 1119-1124.

Forsyth IA 1982 Growth and differentiation of mammary glands. In Oxford Reviews of Reproductive Biology, vol 4, pp 47-85. Ed CA Finn. Oxford: Clarendon Press.

Hartmann PE \& Kronfeld DS 1973 Mammary blood flow and glucose uptake in lactating cows given dexamethasone. Journal of Dairy Science 56 896-902.

Hudson S, Mullford M, Whittlestone WG \& Payne E 1976 Bovine plasma corticoids during parturition. Journal of Dairy Science $\mathbf{5 9}$ 744-746.

Kronfeld DS \& Hartmann PE 1973 Glucose redistribution in lactating cows given dexamethasone. Journal of Dairy Science 56 903-908.

Lefcourt AM, Bitman J, Kahl S \& Wood DL 1993 Circadian and ultradian rhythms of peripheral cortisol concentrations in lactating dairy cows. Journal of Dairy Science 76 2607-2612.

Linzell JL \& Peaker M 1974 Changes in colostrum composition and in the permeability of the mammary epithelium at about the time of parturition in the goat. Journal of Physiology 243 129-151.

McFadden HA \& Stelwagen K 1998 Comparative effects of epinephrine on tight junction (TJ) permeability in mammary and non-mammary epithelia. Journal of Dairy Science 81 (Suppl 1) 376.

McRoberts JA \& Riley NE 1992 Regulation of T84 cell monolayer permeability by insulin-like growth factors. American Journal of Physiology 262 C207-C213.

McRoberts JA, Aranda R, Riley N \& Kang H 1990 Insulin regulates the paracellular permeability of cultured intestinal epithelial cell monolayers. Journal of Clinical Investigation 85 1127-1134.

Mandel LJ, Bacallao R \& Zampighi G 1993 Uncoupling of the molecular 'fence' and paracellular 'gate' functions in epithelial tight junctions. Nature 361 552-555.

Neville MC \& Peaker M 1981 Ionized calcium in milk and the integrity of the mammary epithelium in the goat. Journal of Physiology 313 561-570.

Paterson JYF \& Linzell JL 1971 The secretion of cortisol and its mammary uptake in the goat. Journal of Endocrinology 50 493-499.

Schneeberger EE \& Lynch RD 1992 Structure, function, and regulation of cellular tight junctions. American Journal of Physiology 262 L647-L661.

Singer KL, Stevenson BR, Woo PL \& Firestone GL 1994 Relationship of serine/threonine phosphorylation/dephosphorylation signalling to glucocorticoid regulation of tight junction permeability and ZO-1 distribution in nontransformed mammary epithelial cells. Journal of Biological Chemistry 269 16108-16115.
Stelwagen K \& Knight CH 1997 Effect of unilateral once or twice daily milking of cows on milk yield and udder characteristics in early and late lactation. Journal of Dairy Research 64 487-494.

Stelwagen K, Davis SR, Farr VC, Eichler SJ \& Politis I 1994a Effect of once daily milking and concurrent somatotropin on milk production and mammary tight junction permeability in cows. Journal of Dairy Science 77 2994-3002.

Stelwagen K, Davis SR, Farr VC, Prosser CG \& Sherlock RA $1994 b$ Epithelial cell tight junction integrity and mammary blood flow during an extended milking interval in goats. Journal of Dairy Science 77 426-432.

Stelwagen K, Politis I, White JH, Zavizion B, Prosser CG, Davis SR \& Farr VC 1994c Effect of milking frequency and somatotropin on the activity of plasminogen activator, plasminogen and plasmin in bovine milk. Journal of Dairy Science 77 3577-3583.

Stelwagen K, Farr VC, Davis SR \& Prosser CG 1995 EGTA-induced disruption of epithelial cell tight junctions in the lactating caprine mammary gland. American Journal of Physiology 269 R848-R855.

Stelwagen K, Knight CH, Farr VC, Davis SR, Prosser CG \& McFadden TB 1996 Continuous versus single drainage of milk from the bovine mammary gland during a 24-hour period. Experimental Physiology 81 141-149.

Stelwagen K, Farr VC, McFadden HA, Prosser CG \& Davis SR 1997a Time course of milk accumulation-induced opening of mammary tight junctions and blood clearance of milk components. American Journal of Physiology 273 R379-R386.

Stelwagen K, Verkerk GA, Phipps AM \& Matthews LR $1997 b$ Effect of cortisol on mammary tight junction (TJ) permeability in lactating cows. Livestock Production Science 50 39-40.

Stelwagen K, Farr VC, Davis SR \& McFadden HA 1998a Inhibition of milk secretion and the extent of filling of the bovine mammary gland. Journal of Dairy Science 81 (Suppl 1) 376.

Stelwagen K, McLaren RD, Turner SA, McFadden HA \& Prosser CG $1998 b$ No evidence for basolateral milk protein secretion in the lactating goat mammary gland. Journal of Dairy Science 80 434-437.

Stewart HJ \& Thompson GE 1984 Adrenocorticotrophic hormone stimulation of mammary secretion in lactating goats independent of increased mammary uptake of glucose. Journal of Endocrinology 101 203-211.

Verkerk GA, Macmillan KL \& McLeay LM 1994 Adrenal cortex response to adrenocorticotropic hormone in dairy cattle. Domestic Animal Endocrinology 11 115-123.

Verkerk GA, Phipps AM, Carragher JF, Matthews LR \& Stelwagen K 1998 Characterization of milk cortisol concentrations as a measure of short-term stress responses in lactating dairy cows. Journal of Animal Welfare 7 77-86.

Wilde CJ, Henderson AJ, Knight CH, Blatchford DR, Faulkner A \& Vernon RG 1987 Effects of long-term thrice-daily milking on mammary enzyme activity, cell population and milk yield in the goat. Journal of Animal Science 64 533-539.

Wilde CJ, Addey CVP, Boddy LM \& Peaker M 1995 Autocrine regulation of milk secretion by a protein in milk. Biochemical Journal 305 51-58.

Zettl KS, Sjaastad MD, Riskin PM, Parry G, Machen TE \& Firestone GL 1992 Glucocorticoid-induced formation of tight junctions in mouse mammary epithelial cells in vitro. Proceedings of the National Academy of Sciences of the USA 89 9069-9073.

Received 30 January 1998

Accepted 26 May 1998 